ks. Andrzej Baczyński

\title{
Zasady realizacji programów religijnych w mediach audiowizualnych
}

Instrukcja duszpasterska Communio et progressio ujmując temat programów religijnych w radio i telewizji podaje krótko: „Aspekty religijne życia ludzkiego powinny mieć godne i stałe miejsce w programach" ${ }^{\text {. Tenże }}$ dokument wymienia także pozytywne strony telewizyjnych audycji o charakterze religijnym. Zalicza do nich: kształtowanie pomiędzy wiernymi nowych stosunków, wzbogacanie pobożności i życia duchowego, uzupełnianie wiedzy religijnej, uwrażliwianie na potrzeby Kościoła, świata i innych ludzi, dopomaganie chorym i starszym, którzy nie mogą bezpośrednio uczestniczyć w życiu Kościoła. Instrukcja zwraca również uwagę na użyteczność programów religijnych w dziedzinie nawiązywania serdecznych stosunków z tymi, „którzy chociaż są oddaleni od wspólnoty kościelnej, albo odłączają się od niej, jednak podświadomie szukają duchowego pokarmu" "2. Niebagatelne znaczenie ma również wymiar ewangelizacyjny programów religijnych w telewizji. Chodzi o przekazywanie posłannictwa ewangelicznego tam, gdzie Kościół Chrystusowy nie prowadzi swej działalności³

Wyróżnienie w medialnym przekazie treści religijnych wymiarów istotnych dla misji Kościoła wynika - jak podkreśla instrukcja Aetatis novae - z wizji społecznego przekazu jako drogi do wspólnoty ${ }^{4}$. Komunikowanie to przede wszystkim dawanie siebie z miłości ${ }^{5}$. Ta właśnie wizja leży u podstaw instrukcji Communio et progressio. W tym sensie społeczny przekaz stanowi odzwierciedlenie kościelnej wspólnoty i może się przyczynić do jej rozwoju.

\footnotetext{
${ }^{1}$ CP 149.

${ }^{2} \mathrm{CP} 150$.

${ }^{3}$ Por. tamże.

${ }^{4}$ Por. AN 6.

${ }^{5}$ Por. CP 8.
} 


\section{Forma programów}

Termin program religijny (choć powszechnie używany) nie należy do określeń precyzyjnych i nie odpowiada w pełni rzeczywistości telewizyjnej, w jakiej funkcjonuje. Odwołuje się bowiem do wyizolowanej formuły programów o zawężonym zakresie tematycznym. W tym sensie można mówić np. o programach dla dzieci, o programach dla dorosłych, o programach przyrodniczych, co nie oznacza, że nie mogą istnieć programy bez owego zaszeregowania z udziałem treści przeznaczonych dla określonego kręgu odbiorców. Podział ten należy więc traktować jedynie jako pewną próbę schematyzacji programów telewizyjnych. Nie trzeba dodawać, że tego typu „zaszeregowanie” nie jest najlepszym rozwiązaniem dla obecności Kościoła w mediach masowych, bowiem ogranicza potencjalną widownię przez zbyt mocno zaznaczoną specjalizację.

Pragnieniem Kościoła jest, by wszystkie programy telewizyjne wolne były od fałszu i przekazywały prawdę o świecie i człowieku, by broniły godności człowieka i opowiadały się po stronie tego, co dobre, piękne i sprawiedliwe. Programy tworzone w respekcie dla tych wartości są w centrum zainteresowania Kościoła. Mają swój kontekst religijny, chociaż nie jest on zawsze wyrażony w postaci wyraźnych skojarzeń z Kościołem czy religiąa

Natomiast programami ściśle religijnymi można nazwać te, które ukazują rzeczywistość konkretnie odczytywaną jako kościelną, mogą nimi być np.: relacje z nabożeństw, reportaże z procesji Bożego Ciała, fragmenty mszy świętej, relacje z Drogi Krzyżowej z udziałem Ojca św. celebrowanej w Wielki Piątek i inne tego typu audycje. Często nie występują one samodzielnie, ale wchodzą w skład szerszych formuł programowych, jakimi są np. magazyny telewizyjne. Jest to forma mozaikowa, złożona z różnych elementów, zatem ciekawsza, bardziej urozmaicona i przeznaczona dla szerokiego kręgu odbiorców. W magazynie katolickim znajdą się więc obok siebie zarówno felietony, krótkie reportaże, dyskusje w studio, jak i krótkie relacje z uroczystości kościelnych czy informacje z życia Kościoła lokalnego. Takie formy programów religijnych cieszą się dużą popularnością. Lapidarność, sugestywność obrazu, zmienność gatunków dziennikarskiej wypowiedzi w obrębie jednego programu - wszystko to sprawia, że język magazynów telewizyjnych jest atrakcyjny i pozwala w krótkim czasie przekazać wiele istotnych treści.

${ }^{6}$ Troska Kościoła o odpowiedni poziom etyczny programów telewizyjnych znalazła swój pierwszy instytucjonalny wyraz już w latach pięćdziesiątych ubiegłego stulecia, w encyklice Piusa XII Miranda prorsus, gdzie jest mowa o dość rygorystyczno potraktowanym zaleceniu przestrzegania zasad religijnych i moralnych w tworzeniu programów telewizyjnych. Por. PIus XII, Miranda prorsus, [w:] Kościót a kultura masowa, red. F. Adamski, Kraków 1984, s. 259. 
Trzeba dodać, że program religijny w telewizji nie korzysta z jakiegoś specjalnie wypracowanego na własny użytek modelu. W jego konstrukcji odnaleźć można prawie wszystkie możliwe (dla danego okresu rozwoju medium audiowizualnego) środki wypowiedzi. Obok wspomnianych w instrukcji Communio et progressio: transmisji mszy świętej, nabożeństw, pogadanek, wykładów, serwisów informacyjnych i programów dyskusyjnych, pojawily się nowe, często związane z rozwojem techniki audiowizualnej, np. programy realizowane w wirtualnym studio. Programy religijne nie stronią od reportażu i dokumentu, typowo telewizyjnych form przekazu, najwierniej opisujących rzeczywistość. Nowością w programach religijnych jest niewątpliwie adaptowanie form dotychczas nieznanych w temacie religijnym, jak: teleturniej (współzawodnictwo rodzin w tematyce biblijnej), studio „na żywo” (z udziałem publiczności), łączenia „na żywo” w ramach akcji dobroczynnych Caritas (Adwentowa świeca) czy bezpośrednie transmisje z Watykanu modlitwy Ojca Świętego Anioł Pański.

Od strony formalnej program religijny podlega tym samym regułom, co inne wytwory twórczości telewizyjnej. Profesjonalizm, znajomość zarówno tematyki poszczególnych programów, jak i języka audiowizji, rzetelne podejście do pracy, kompetencja - to podstawy warsztatu twórcy programów telewizyjnych, również tych określanych jako religijne ${ }^{7}$.

Dziennikarstwo telewizyjne opiera się na specyfice medium audiowizualnego. Jego istotą i siłą jest szybkość przekazu informacji, aktualność, autentyzm, konkret, swoista widzialność wydarzeń, a także personalistyczny sposób przekazu (dziennikarz wprost do kamery lub z tzw. offu ${ }^{8}$ relacjonuje, komentuje zdarzenia i zjawiska). Telewizyjna forma wypowiedzi jest bardziej zakotwiczona w życiu człowieka i często odwołuje się do emocji ${ }^{9}$. Tym różni się od przepowiadania kościelnego, które często nie jest zbyt mocno związane z życiem, przejawia tendencję do abstrakcyjnego rozumowania, do ogólnych prawd, do dogmatyzowania zasad i mądrych cytatów.

Bezpośredniość i autentyzm obrazu telewizyjnego ma niezwykłą siłę oddziaływania. Widz oglądając program telewizyjny ma szansę zobaczyć, jak inni żyją, jakie mają problemy, doświadczenia, może również doznać religijnych przeżyć poprzez przekaz i świadectwo wiary innych ludzi. Wszystko to dzieje się w obszarze języka audiowizualnego, prostego i zrozumiałego dla wszystkich.

${ }^{7}$ Por. JAN PAWE⿺ II, Religia w środkach przekazu, „L'Osservatore Romano” 1989, nr 1-2, s. 28.

${ }^{8}$ Termin techniczny - głos dochodzący spoza kadru.

${ }^{9}$ Por. P. GHeddo, Gtoszenie Ewangelii w epoce środków masowego przekazu, „Communio” 1995, nr 6, s. 98-99. 
Programy religijne w telewizji powinny szczególnie pielęgnować te formy wypowiedzi, które ukazują prawdę o świecie i o życiu innych ludzi, nie stroniąc od ukazywania problemów wiary w oparciu o konkretne świadectwa. Takie przekazy mają największą oglądalność i najbardziej oddziaływują na odbiorców. „Człowieka interesuje człowiek”10. Telewizyjna wypowiedź bazująca na sugestywnym obrazie i dźwięku daje poczucie swoistej obecności. To odczucie wyzwala u odbiorców szczególną solidarność z człowiekiem potrzebującym i cierpiącym. Dziś jest już prawidłowością, że twórcy tego typu programów korzystają ze wszystkich form wypowiedzi charakterystycznych dla medium telewizyjnego. To treść programów, idee, prezentowany świat wartości wskazują na to, czy dana audycja może pretendować do roli programu religijnego. Praktyka polskiej telewizji publicznej wskazuje na jeszcze jedną możliwość - wyróżnikiem programów religijnych może stać się komórka organizacyjna, która tworzy określone programy. W przypadku programów religijnych jest nią Redakcja Programów Katolickich. Redakcja ta koordynuje transmisje z uroczystości kościelnych na antenie ogólnopolskiej, w szczególności przekazy z Watykanu, i zajmuje się produkcją konkretnych programów katolickich w ramach przydzielonych pasm antenowych.

\section{Tematyka programów}

„Jest rzeczą konieczną - naucza instrukcja Aetatis novae - aby środki przekazu uwzględniały całościowy rozwój osoby, obejmujący kulturowy, transcendentny i religijny wymiar człowieka i społeczeństwa, i przyczyniały się do jego rozwoju" ". Jan Paweł II w przemówieniu do dziennikarzy zwrócił uwagę na rosnące znaczenie informacji o człowieku, która będąc w obiegu przekazu masowego, pozwala, aby cały świat uczestniczył w problemach nurtujących zarówno jednostki, jak i cały rodzaj ludzki ${ }^{12}$. Aby tak się stało, musi zostać wypracowana owa informacja i nadana przez przekaźnik, który jest już tylko techniczną finalizacją powziętych zamierzeń. Zadanie wypracowania treści i przesłania ich należy do człowieka, pracownika środków przekazu. Papież podkreśla osobowy charakter tego procesu: ,jesteśmy świadomi, że za kamerami znajduje się konkretny człowiek, że ktoś mówi do mikrofonu, że ktoś wygładza i poprawia każdy wiersz artykułu, który jutro opublikuje"13.

${ }^{10}$ P. GHEDDo, Gtoszenie Ewangelii w epoce środków masowego przekazu, dz. cyt., s. 98.

${ }^{11}$ AN 7.

${ }^{12}$ Por. JAn PaweŁ II, Przemówienie do dziennikarzy w Kolegium Forida w mieście Meksyku, [w:]Jan Pawet II w Ameryce Łacińskiej, Warszawa 1980, s. 153.

${ }^{13}$ Tamże, s. 152. 
Twórczy charakter pracy w mediach przejawia się w wyborze treści, nadawaniu formy, a także w kształtowaniu rzeczywistości prezentowanej w konkretnym programie. Przekaz nie poprzestaje na prostej reprodukcji świata czy zewnętrznym opisie. Posiada możliwość takiego skondensowania rzeczywistości obrazowej, by przekazać w słowie, dźwięku lub obrazie coś z prawdy świata i głębi człowieka ${ }^{14}$.

W pierwszym rzędzie programy o charakterze religijnym powinny wszechstronnie zajmować się człowiekiem, jego problemami, w tym również sprawą życia religijnego. Wynika to z rozumienia misji Kościoła w świecie. Prawdę tę przypomina Jan Paweł II w encyklice Redemptor hominis: „człowiek jest drogą Kościoła, drogą jego codziennego życia i doświadczenia, posłannictwa i trudów - Kościół naszej epoki musi być wciąż na nowo świadomy jego sytuacji - to znaczy świadomy równocześnie jego możliwości, [...] zagrożeń, [...] aby wszystko, co na to życie się składa, odpowiadało prawdziwej godności człowieka"15.

Współczesny człowiek zalewany potokiem informacji, zmęczony nadmiarem skomplikowanej techniki, szuka nade wszystko spokoju, takich warunków życia, które mu pozwolą prawdziwie doskonalić swoją osobowość. W tym procesie środki przekazu mogą okazać się pomocne. Stąd odbiorcy telewizyjnych przekazów szukają na ekranie prawdy o swoim życiu, o tajemnicach duszy ludzkiej, prawdy o świecie, o człowieku, o prawdziwym szczęściu, o pełni człowieczeństwa. Szukają prawdy obiektywnej i uczciwie podanej ${ }^{16}$. Szeroko pojmowany temat człowieka i jego życia jest niewątpliwie jednym z głównych obszarów zainteresowań telewizji, choć nie zawsze widziany we właściwej dla pełni życia ludzkiego perspektywie. Od programu katolickiego w telewizji można więc domagać się pełnego ujęcia tematu człowieka, w całej jego duchowo-cielesnej głębi.

Tematem szczególnie nośnym dla telewizji jest rodzina. Jan Paweł II naucza, iż mówiąc o rodzinie „należy szerzyć zdrowe wartości moralne i duchowe, unikając wszystkiego, co mogłoby zaszkodzić istnieniu, trwałości, harmonii i szczęściu rodziny, a więc pornografii i przemocy, propagowania rozwodów lub aspołecznych postaw wśród młodzieży"17. Mówiąc o problematyce rodzinnej w mediach Papież podaje tematy, których nie należy unikać w programach telewizyjnych.

${ }^{14}$ Por. JAN PAweŁ II, Kościót potrzebuje sztuki (przemówienie do uczestników IV Zgromadzenia Plenarnego Papieskiej Komisji ds. Kościelnych Dóbr Kultury z 19 października 2002).

${ }^{15} \mathrm{RH} 14$

${ }^{16}$ Por. K. Chudy, Zainteresowanie Kościoła środkami audiowizualnymi, [w:] Kościót a kultura masowa, dz. cyt., s. 87-88.

${ }^{17}$ JAN PAWEŁ II, Telewizja w rodzinie: kryteria wtaściwego wyboru, „L'Osservatore Romano” 4 (1994), s. 8. 
„Telewizja musi często podejmować poważne tematy, takie jak ludzka słabość i grzech, oraz ich konsekwencje w życiu jednostek i społeczeństwa; niedostatki instytucji społecznych, w tym także władzy i religii; fundamentalne pytania o sens życia. Powinna jednak podchodzić do nich w sposób odpowiedzialny - nie goniąc za sensacją, ale troszcząc się szczerze o dobro społeczeństwa i dbając o skrupulatne przekazywanie prawdy. Prawda was wyzwoli (J 8, 32) - powiedział Jezus, zaś wszelka prawda ma swój najgłębszy fundament w Bogu, który jest też źródłem naszej wolności i twórczości”"18.

$\mathrm{Z}$ problematyką rodzinną wiąże się temat szacunku dla życia. Rola mediów katolickich w tej sprawie jest znaczna. Telewizja jako największy środek przekazu może w dziedzinie upowszechniania wiedzy o nienaruszalności życia ludzkiego od samego poczęcia aż do naturalnej śmierci wiele zdziałać. We współczesnej telewizji, zwłaszcza komercyjnej, niekiedy także publicznokomercyjnej (jak w przypadku telewizji polskiej), zauważa się atmosferę niesprzyjającą ukazywaniu prawidłowej wizji życia, co w znacznej mierze jest wynikiem propagowania określonej ideologii lub przyjmowania postaw konformistycznych. Stąd na twórcach programów religijnych spoczywa obowiązek podejmowania problematyki świętości życia ludzkiego i obrony życia nienarodzonych. Adhortacja Christifideles laici zwraca uwagę, że Kościół broniąc życia realizuje zasadniczy wymiar swego posłannictwa ${ }^{19}$. W adhortacji Familiaris consortio czytamy, iż Kościół „mocno wierzy, że życie ludzkie, nawet gdy słabe i cierpiące, jest zawsze wspaniałym darem Bożej dobroci. Przeciw pesymizmowi i egoizmowi, zaciemniającemu świat, Kościół opowiada się za życiem: w każdym życiu ludzkim umie odkryć wspaniałość owego Tak, owego Amen, którym jest sam Chrystus (por. 2 Kor. 1, 19; Ap 3, 14). Owemu Nie, które zalewa i gnębi świat, przeciwstawia żyjące Tak, broniąc w ten sposób człowieka i świat przed tymi, którzy czyhają na życie i zadają mu śmierć"20.

Adhortacja Chrisifideles laici szczególną troskę o życie powierza ludziom świeckim, zaangażowanym poprzez powołanie czy wykonywanie pracy w ten temat. Nie są z tego obowiązku, czy przywileju troski zwolnieni dziennikarze, uznający chrześcijański system wartości, nawet wówczas, gdy realizują programy, które trudno określić jako ściśle religijne. Natomiast katolickie programy telewizyjne, realizowane przez świeckich i duchownych mają w tej dziedzinie doniosłą misję do spełnienia - mogą rozjaśniać obszary programowego milczenia wokół tematu poszanowania życia.

\footnotetext{
${ }^{18}$ Tamże.

${ }^{19}$ Por. ChL 38.

${ }^{20}$ FC 30.
} 
Kolejnym medialnym tematem jest obecność Boga, religii, a tym samym Kościoła w programach katolickich. Treści te, na różny sposób prezentowane, mogą pełnić kilka ważnych funkcji: pomóc w ewangelizacji, ukazywać jedność Kościoła i rodzaju ludzkiego, dawać poczucie obecności w życiu Kościoła, dostarczać przeżyć duchowych, umacniać wewnętrznie i uzupełniać niezbędną wiedzę katechetyczną.

Jan Paweł II w adhortacji Catechesi tradendae zwraca uwagę na tę ostatnią funkcję, która może być traktowana jako kontynuacja katechezy ustawicznej. Stąd Papież postuluje, by dzięki mass-mediom „dorośli mogli częściej uzupełnić przerwaną lub niewystarczającą katechezę albo też odpowiednio dopełnić na wyższym poziomie nauczania to, czego się nauczyli w dzieciństwie, czy nawet tak wykształcić się w tej dziedzinie, by mogli pomagać innym"21. Wspomniana już instrukcja Communio et progressio podkreśla natomiast wartość programów o tematyce typowo religijnej dla sprawy podstawowej katechizacji w krajach o dużym procencie analfabetyzmu. „Istotnie, człowieka niewykształconego najbardziej i najmocniej pociągają obrazy, ponieważ przy ich pomocy łatwiej zapoznaje się z rzeczami i pojęciami. W wysiłkach podejmowanych dla postępu ludzkiego i chrześcijaństwa nie powinno się lekceważyć tych tak skutecznych pomocy"22. Tenże sam dokument zwraca również uwagę na tematykę religijną poruszaną w filmie fabularnym, który często stanowi podstawę programu telewizyjnego. Filmy takie pokazywane w kinie, czy też w telewizji „wybitnie sprzyjają postępowi ludzkości i podnoszą ducha” ${ }^{23}$.

Posoborowa Instrukcja rozszerza znacznie zakres tematyki, która powinna być obecna w publicystyce katolickiej, zarówno prasowej, radiowej, jak i telewizyjnej. Według autorów Communio et progressio - tematem jest „cała rzeczywistość oraz jak najszerszy zakres wiadomości, komentarzy opinii, rozpatrujących w różnym aspekcie trudności i problemy dzisiejszego człowieka, zawsze jednak naświetlając je pod kątem chrześcijańskiego poglądu na świat. Do niej również należy uzupełnianie, a jeśli trzeba, prostowanie różnych informacji na temat religii i Kościoła"24.

Zarysowane tematy pokazują, jak wielką rolę mają do spełnienia programy religijne. Do ich najpilniejszych zadań należy niewątpliwie: jednoczenie ludzi, kształtowanie chrześcijańskiego stylu życia, posługa informowania, a także obrona podstawowych wartości ludzkich. Zadania te nabierają szczególnej wagi w obliczu różnorodnych nacisków na przekaz telewizyjny ze strony moż-

\footnotetext{
${ }^{21} \mathrm{CT} 45$.

${ }^{22}$ CP 146.

${ }^{23}$ Tamże, 144.

${ }^{24}$ Tamże, 138.
} 
nych decydentów, którzy w telewizji widzą przede wszystkim łatwy środek manipulacji opinią publiczną i siłę napędu konsumpcyjnego stylu życia.

\section{Prawda w przekazie telewizyjnym}

„Człowiek współczesny powinien być uczciwie, w pełni i wiernie informowany o faktach, aby wśród ciągłej zmienności w dzisiejszych czasach mógł zrozumieć świat, w którym żyje" ${ }^{25}$. Stosunek do prawdy jest podstawowym kryterium oceny wartości programów telewizyjnych, również programów religijnych. Kościół wyraża głębokie przekonanie, że „podstawowym prawem wszelkiego rodzaju przekazu jest szczerość, prawość i prawda. Nie wystarczą zatem dobre chęci i prawość woli [...]. Ponadto należy przekazywać fakty zgodnie z prawdą, to znaczy dawać ich prawdziwy obraz, zgodny z wewnętrzną prawdą przedstawianych wydarzeń”26. „Służyć prawdzie - czytamy w encyklice Miranda prorsus Piusa XII - to nie znaczy tylko trzymać się z daleka od fałszu i błędu, ale także unikać tej tendencyjności i stronniczości, które mogłyby sprzyjać szerzeniu się wśród społeczeństwa błędnych poglądów na życie i ludzkie postępowanie"27.

Człowiek dążąc do poznania prawdy o sobie, dąży jednocześnie do poznania rzeczywistości świata, który go otacza i jest środowiskiem jego życia. Ma więc prawo żądać prawdziwego obrazu świata. Prawda chroni nie tylko materialną dosłowność świata, ale przede wszystkim jego rzeczywiste znaczenie. Jan Paweł II podkreśla, że „Chrystus uczy nas szczególnej wrażliwości na człowieka [...]. Ta wrażliwość jest oznaką poznania wyzwalającej prawdy. Nie wolno człowiekowi zakrywać tej prawdy przed samym sobą. Nie wolno jej zafałszować. Nie wolno czynić jej przedmiotem przetargu. Trzeba mówić o niej w sposób jasny i prosty"28.

Communio et progressio określa wagę prawdy w kontekście funkcji społecznej przekazu. Współczesny człowiek napotyka ogromne trudności w ogarnięciu wszystkich wiadomości, które do niego docierają, ma również trudności w przekazywaniu ich ze swej strony. Natłok informacji powoduje powstawanie poczucia zagubienia, alienacji, niedoinformowania w rzeczach istotnych, nawet frustracji z powodu tzw. „szumu informacyjnego”. Dziennikarstwo oparte na szacunku dla prawdy jawi się szczególnie pomocne w rozjaśnianiu pola informacyjnego. Tymczasem dziennikarze - twierdzą autorzy instrukcji

25 Tamże, 34.

${ }^{26}$ Tamże, 17.

${ }^{27}$ Pius XII, Miranda prorsus, dz. cyt., s. 244.

${ }^{28}$ Jan PAwet II, Przemówienie na audiencji generalnej 21 II 1979 r., [w:] Wy jesteście moja nadzieją. Stowa Jana Pawła II do młodzieży, Łódź 1983, s. 65. 
- zamiast porządkować przebieg informacji, działają wybiórczo, naświetlając tylko część rzeczywistości i podając wiadomości w danej chwili interesujące. Trudność dziennikarskiej pracy w tej dziedzinie polega na tym, że dziennikarze z ogromnego napływu informacji muszą wybierać przede wszystkim informacje ważne, według obowiązującego w danym medium kryterium. Tymczasem wszelka selekcja nie licząca się z dobrem człowieka, merkantylna lub ideologiczna rodzi niebezpieczeństwo pomijania podstawowej i pełnej treści przedstawianych wydarzeń czy też wręcz fałszowania rzeczywistości ${ }^{29}$.

Najczęściej dochodzi dziś do przemilczania pewnych niewygodnych dla określonych środowisk prawd. Chodzi o tzw. prawdy nie na czasie. Nie kwestionuje się tutaj samej prawdy, tylko jej aktualność. Za prawdy nie na czasie uważa się np.: świętość życia, jego nienaruszalność, pojęcie grzechu, rzeczy ostateczne: śmierć, sąd, piekło, czyściec, niebo. W związku z tzw. modą na wygodne życie, za prawdy nie na czasie uważa się wszystko to, co mogłoby burzyć spokój sumienia, wskazywać na konieczność podejmowania wysiłku, uwypuklać wartość poświęcenia i ofiary (podkreśla się, że msza święta jest uczta, przemilcza się natomiast fakt, że jest też ponowieniem ofiary krzyżowej Chrystusa). Chrześcijaństwo tak prezentowane ma charakter wybiórczy (selektywny), sielankowy, horyzontalny (sprowadza zbawienie do pomyślności doczesnej), a nierzadko minimalistyczny.

Inna trudność wynika z szybkości przebiegu informacji, co prowadzi do swoistego współzawodnictwa w nadawaniu wiadomości. W tej sytuacji powstają braki we właściwym przedstawianiu faktów. Dotyczyć to może również informacji religijnej.

Poza tymi niedogodnościami, które wynikają z nadmiaru informacji, ludzkich ograniczeń oraz charakteru środków przekazu, pojawia się również problem formy przekazu. Zgodnie z telewizyjną regułą - forma winna być atrakcyjna, żywa, przystosowana do mentalności odbiorców i ich zdolności percepcyjnych. Prawdziwa sztuka dziennikarska polega na wyborze takiej formy przekazu, by poruszyła odbiorców, a nie prowadziła do deformacji wiadomości, wyolbrzymiania faktów, przejaskrawienia szczegółów, gonitwy za sensacją. W przeciwnym razie odbiorcy otrzymają atrakcyjnie ukazany obraz rzeczywistości, niekiedy z dużym ładunkiem dramatyzmu, ale nie odpowiadający prawdzie. Communio et progressio naucza, iż „w tych trudnych warunkach dziennikarze powinni trzymać się ściśle prawdy przy podawaniu informacji” ${ }^{30}$.

${ }^{29}$ Por. CP 37.

${ }^{30}$ CP 39. 
Wierność prawdzie w przekazie telewizyjnym (każdego rodzaju) zobowiązuje do tego, aby nie opierać się na wątpliwych źródłach, by nie wyolbrzymiać faktów o mniejszym znaczeniu, nie poddawać się naciskowi opinii publicznej ani pokusie interesownej sensacji, wreszcie by nie przystępować do opcji stronniczej, zwłaszcza gdy chodzi o politykę ${ }^{31}$.

$\mathrm{Z}$ problemem prawdy w przekazie telewizyjnym, wiąże się kwestia prezentowania realności zła na ekranie. Jan Paweł II twierdzi, iż przywrócić oblicze prawdy w mediach oznacza „nazwać po imieniu - każdy akt przemocy, w jakiejkolwiek formie on się przejawia" "32, nazwać zło, ponieważ zło należy do prawdy tego świata, ,jest realnością, której rozmiary przeżyło i odczuło szczególnie nasze stulecie aż do granic" ${ }^{33}$. Nie można zatem zrezygnować z przedstawiania zła w różnych jego formach i postaciach. Nie jest to jednak otwarcie bram dla zła w środkach przekazu, chodzi raczej o ukazanie jego miejsca w rzeczywistości ${ }^{34}$. Nadmiar zła, przemocy może bowiem prowadzić do zasmakowania w złu, wtedy staje się ono celem samym w sobie. Jan Paweł II poucza, że jedyną możliwą i usprawiedliwioną intencją ukazywania realizmu zła w mediach, szczególnie w telewizji, jest wstrząśnięcie odbiorcą, by uświadomił sobie niszczącą siłę zła i odwrócił się od niego ${ }^{35}$. Papież zaleca jednocześnie wielką ostrożność w ukazywaniu zła, by nie sugerować, iż jest to jedyna prawda o świecie i człowieku. Dotyczy to szczególnie odbiorców młodych, nieprzygotowanych, przypadkowych, zatrzymujących się tylko na sferze obrazkowej przekazu, a nie wnikających w głębię problemu.

Dekret Inter mirifica, pisząc o prezentacji przejawów zła w świecie, podaje, iż przy zaistnieniu odpowiednich warunków, przedstawianie zła moralnego w mediach może służyć lepszemu i głębszemu poznaniu człowieka. „Przy użyciu odpowiednich form dramatycznych można w ten sposób zobrazować i uwypuklić wspaniałość prawdy"36. Istotne dopowiedzenie do problemu obecności brutalnej prawdy, również o złu w mediach, wnosi soborowa deklaracja $O$ wolności religijnej. Prawdy - w myśl tego dokumentu - „trzeba szukać w sposób zgodny z godnością osoby ludzkiej i jej naturą społeczną"37. Bowiem prawda o dobru, a nie o złu stanowi o wielkości i godności człowieka. W imię tej godności Jan Paweł II postuluje, by nie przesłaniano w mediach obrazem negatywnym i zalewem zła - dobra i nadziei, która spra-

\footnotetext{
${ }^{31}$ Por. JAN PAwEe II, Informacja, świadectwo, prawda, „L'Osservatore Romano” 5-6 (1983), s. 9.

32 JAN PAwEE II, Prawda sita pokoju, „LOSsservatore Romano” 1-2 (1980), s. 3.

${ }_{33}^{3}$ Jan PaWeŁ II, Kościót potrzebuje sztuki, dz. cyt., s. 18.

${ }^{34}$ Por. tamże.

${ }^{35}$ Por. tamże.

${ }^{36}$ IM 7.

${ }^{37}$ DWR 3.
} 
wia, że staje się „możliwe przeżywanie dobra z intensywnością, co najmniej dorównującą tej, z którą przeżywa się rzeczy przykre"38.

Dekret Inter mirifica naucza, że kryterium prawdy w mediach oznacza dla dziennikarzy i twórców, by zawsze przestrzegali zasad obiektywizmu i szczerości, przy zachowaniu sprawiedliwości i miłości, a także norm moralnych oraz słusznych praw i godności człowieka, zarówno przy zbieraniu informacji, jak i przy ich rozpowszechnianiu. „Nie każda bowiem wiadomość jest pożyteczna, a miłość buduje (1 Kor 8, 1)" ${ }^{39}$.

Obowiązek przekazywania prawdy dotyczy wszelkich aspektów życia ludzkiego, a więc i sfery życia religijnego. Zastrzeżenie to wynika, zdaniem Jana Pawła II, z istniejących tendencji marginalizowania tematu religijnego i ciągle kurczącego się czasu antenowego na sprawy religii w mediach publicznych i komercyjnych ${ }^{40}$. Dochodzi do tego specyficzne traktowanie przekazu o charakterze religijnym. Zwykle bywa on ukazywany na obrzeżach działania telewizji, w aspektach drugorzędnych lub pod kątem deformującym treśćc1. Pius XII, u początków rozwoju telewizji w Europie, w encyklice Miranda prorsus, opublikowanej w 1957 roku pouczał, iż należy dążyć do tego, aby prawdy objawione były w mediach uważane za święte, a treści przekazów audiowizualnych szerzyły wśród wszystkich wiarę w Boga i w Jezusa Chrystusa - „tę wiarę, która sama jedna może dać milionom ludzi siłę do zniesienia z pogodą ducha i odwagą niewypowiedzianych doświadczeń i trosk chwili obecnej”42. Jan Paweł II, realistycznie oceniając obraz mediów końca XX wieku, uważa za swoją pasterską powinność żądanie respektu dla prawdy w prezentowaniu religii, prawdy o nauce objawionej, o Kościele i Biskupie Rzymu, prawdy o misji pokoju, pojednania i miłosierdzia realizowanej przez Stolicę Apostolską.

Prawda, według Jana Pawła II, nie jest tylko czynnikiem rozwoju ludzkiej świadomości i pogłębienia w ten sposób życia wewnętrznego, nie jest tylko warunkiem realizacji wolności człowieka. Prawda ma swój wyższy sens religijny, sens profetyczny. Takie rozumienie prawdy jest głęboko zakorzenione w Ewangelii. Chrystus dał przykład mocy profetycznej, jaka zwiera się w prawdzie. On też jako świadek prawdy przeciwstawiał się wszystkiemu, co stanowiło nieprawdę, fałsz i zakłamanie ${ }^{43}$.

${ }^{38}$ JAN PAWEE II, Spotkanie z przedstawicielami świata nauki i sztuki, „L'Osservatore Romano” 9 (1983), s. 14.

${ }^{39}$ IM 5

${ }^{40}$ Por. Jan Pawex II, Kościót potrzebuje sztuki, dz. cyt., s. 18.

${ }^{41}$ Por. tamże.

${ }^{42}$ Pius XII, Miranda prorsus, dz. cyt., s. 244.

${ }^{43}$ Por. Jan Pawee II, Przemówienie na audiencji generalnej, 21 II 1979 r., [w:] Wy jesteście moją nadzieja, dz. cyt., s. 65. 
Prawda w ukazywaniu ważnych faktów - tzn. takich, które wnoszą coś do obiektywnego osądu rzeczywistości ludzkiego życia z punktu widzenia ekonomii, polityki, kultury, pedagogiki, religii - sprzyja refleksji nad wartościami, które budują człowieka i dopomagają w usłyszeniu ewangelicznego wezwania. Jeśli chodzi o fakty religijne to - zdaniem Jana Pawła II - „wierzący dziennikarz będzie służył prawdzie wówczas, gdy będzie starał się ukazać je od wewnątrz, uwzględniając intencję wiary i odwołując się do tajemnicy, która w niej się kryje, nie ograniczając się do ukazania ich jedynie jako prostego faktu kulturowego"44.

Problem prawdy leży więc w wyborze tego, co najlepiej - a nie wycinkowo i stronniczo - odzwierciedla rzeczywistość. Odnosząc sugestie Jana Pawła II wysuwane pod adresem prasy katolickiej do programów telewizyjnych, należy dodać, że chodzi o takie kształtowanie programów katolickich, by odbiorcy, kimkolwiek są, mieli pewność odnalezienia w nich ludzi, którzy prawdziwie wierzą i są szczęśliwi należąc do Kościoła, a przez to uczą innych kontemplować go i kochać ${ }^{45}$. „Wchodzi to w zakres tej wierności - mówił Jan Paweł II do dziennikarzy katolickich - bez której stracilibyście rację bytu, i współbrzmi z waszym obecnym nastawieniem, wyznawanym przez was przywiązaniem do Kościoła, które przychodzicie umocnić u Następcy Piotra"46.

Prawda w ukazywaniu różnych wydarzeń pozwala odbiorcom „uformować w sobie ludzki i chrześcijański sąd, zdolny służyć każdemu człowiekowi i każdego dowartościowujący, sąd, który otworzy drogi dla nadziei i miłości. Czyż w tych dwóch punktach nie wyraża się specyficzna cecha katolickiego dziennikarstwa?" 47 . Prawda w mediach oznacza równocześnie, że dobro będzie nazwane zawsze dobrem, a zło złem. Dobro to - sprawiedliwość, miłość i uczciwość. Zło - to przede wszystkim przemoc, nienawiść, egoizm, niemoralność i wszelka wada, nawet jeśli towarzyszy jej dobrobyt i luksus ${ }^{48}$. Kłamstwo, nieprawda stoją u podstaw przemocy w świecie. Kłamstwo wypacza istotę komunikacji, mającej służyć umacnianiu więzi międzyludzkich i tworzyć punkty odniesienia dla wzajemnego porozumienia.

\section{Odpowiedzialność za treść przekazu}

Pius XII we wspominanej już encyklice Miranda prorsus zwrócił uwagę na konieczność przyjęcia odpowiedzialności za treści prezentowane w te-

\footnotetext{
${ }^{44}$ JAN PAWEx II, Informacja, świadectwo, prawda, dz. cyt., s. 9.

${ }^{45}$ Por. tamże.

${ }^{46}$ Tamże.

${ }^{47}$ Tamże.

${ }^{48}$ Por. Jan PaweŁ II, Prawa i obowiązki dziennikarza, „L'Osservatore Romano” 7-8 (1982), s. 21.
} 
lewizji. Przyjęcie odpowiedzialności dotyczy zarówno środowiska twórców, jak i odbiorców. Twórców - za staranne i uczciwe przygotowywanie programów telewizyjnych, by odpowiadały etycznym wymaganiom. Odbiorców - za roztropne i czujne korzystanie z telewizji. „Właściwe jej użycie i roztropne, stosowne do wieku, udostępnianie jej dzieciom, należyta ocena oglądanych programów, a wreszcie uchronienie dzieci przed mniej skromnymi widowiskami - oto nakazy, które poważnie obarczają sumienia rodziców i wszystkich tych, na których ciąży obowiązek wychowania młodzieży"49.

Odwołując się do odpowiedzialności twórców i dziennikarzy telewizyjnych, Papież apeluje o sumienne przestrzeganie zasad religijnych i moralnych w treści programów telewizyjnych. W sprawach wątpliwych, szczególnie wtedy, gdy zachodzi konflikt pomiędzy sztuką a religią i moralnością, należy - zdaniem Piusa XII - zasięgnąc kompetentnej rady, mając na uwadze zarówno dobro duchowe widzów, jak i doskonałość dzieła. Papież zachęca, by zwracać się o pomoc do odpowiednich katolickich urzędów, podkreślając równocześnie, że osoby duchowne bez zezwolenia władzy kościelnej i merytorycznego przygotowania nie mogą pełnić funkcji doradczych.

W odniesieniu do katolickich twórców i reżyserów filmowych Pius XII kieruje napomnienie, by nie zgadzali się na tworzenie dzieł sprzeciwiających się wierze i chrześcijańskim obyczajom. Wskazuje równocześnie, iż nic tak skutecznie nie przyczynia się do podźwignięcia twórczości filmowej na wysoki poziom, jak kształtowanie środowiska twórców według zasad chrześcijańskich. „Oni bowiem, jeżeli się zbliżą do źródeł łaski, jeżeli przyswoją sobie naukę ewangeliczną, jeżeli poznają zasady, które Kościół głosi o prawdzie życia, o szczęśliwości i cnocie, o bólu i grzechu, o ciele i duszy, o stosunkach społecznych i wreszcie o pragnieniach serc ludzkich - odkryją nowe i wspaniałe drogi twórczości oraz znajdą nową zachętę do tworzenia wielkich i trwałych dzieł"50.

Dekret Inter mirifica poucza, iż w przypadku kontrowersji pomiędzy etyką a estetyką należy uznać prymat obiektywnego porządku moralnego, który bezwzględnie powinien być przestrzegany przez wszystkich twórców. „Przewyższa on bowiem wszystkie inne porządki spraw ludzkich, choćby o wielkim znaczeniu - nie wyłączając estetycznego - oraz należycie je w stosunku wzajemnym do siebie ustawia. Albowiem tylko porządek moralny obejmuje całą naturę człowieka, będącego rozumnym stworzeniem Bożym, powołanym do spraw wyższych. Jeśli porządek ten zostanie przez człowieka całkowicie i wiernie zachowany, doprowadzi go do osiąnnięcia pełni doskonałości i szczęścia"51.

\footnotetext{
${ }^{49}$ PIUs XII, Miranda prorsus, dz. cyt., s. 259.

${ }^{50}$ Tamże, s. 252.

${ }^{51}$ IM 6.
} 
Odpowiedzialność twórców za treść i formę przekazu wiąże się przede wszystkim z ogromnym wpływem, jaki media audiowizualne wywierają zarówno na indywidualne, jak i społeczne życie ludzi ${ }^{52}$. Wpływ ten oznacza możliwość prowadzenia człowieka i całych społeczności ku dobru lub ku $\mathrm{złu}^{53}$. Ojcowie soborowi zachęcają, by twórcy i dziennikarze, w poczuciu odpowiedzialności za efekty społeczne swojej pracy, wstępowali do organizacji i związków zawodowych, które zobowiązują swoich członków do należytego zachowywania kodeksu moralnego. Równocześnie, z tych samych powodów, autorzy Dekretu postulują, by opracowywanie programów o treści religijnej powierzane było „osobom godnym i doświadczonym, oraz by wykonywano je z należytym szacunkiem" ${ }^{4}$.

Communio et progressio rozszerza zakres odpowiedzialności środowiska twórców na funkcjonowanie przekazu w społeczeństwie i kwestię realizacji misji środków przekazu. Celem działania mediów (wynikającym z natury społecznego przekazu) jest dążenie do zbliżenia i prawdziwego zjednoczenia wszystkich ludzi, a także popieranie postępu ludzkiego. Stąd realizatorzy programów telewizyjnych powinni już przy doborze tematów zatroszczyć się o całokształt potrzeb społeczeństwa. „Jedynie dzięki ludziom specjalnie do tego przygotowanym, wolnym i odpowiedzialnym za swoje obowiązki może zaistnieć w społeczeństwie ludzkim ta rozległa i ciąła wymiana myśli, rozpowszechniana przez środki społecznego przekazu" ${ }^{5}$. Instrukcja zdecydowanie odrzuca takie postępowanie twórców, które podyktowane jest jedynie chęcią zdobycia pieniędzy i próżnej sławy. Dokument podkreśla natomiast potrzebę sformułowania kodeksu postępowania w dziedzinie społecznego przekazu. Normy i reguły postępowania twórczego winny być - w myśl Instrukcji- „raczej pozytywne niż negatywne i powinny podawać nie tylko to, czego należy unikać, ale raczej to, co należy czynić dla lepszej służby ludzkości”"56.

Problem odpowiedzialności za treść społecznego przekazu zajmuje centralne miejsce w nauczaniu Jana Pawła II o mass mediach. Dotyczy ono wszystkich środków przekazu, ze szczególnym wskazaniem telewizji jako największego z publikatorów. Kwestię odpowiedzialności zawodowej, odpowiedzialności za twórczy efekt swej pracy i przewidywany wpływ na odbiorców Jan Paweł II podnosi do rangi podstawowego wymagania, stawianego przed pracownikami mediów.

\footnotetext{
${ }^{52}$ Por. tamże, 7.

${ }^{53}$ Por. tamże, 11.

${ }^{54}$ Tamże.

${ }^{55} \mathrm{CP} 74$.

${ }^{56}$ Tamże, 79.
} 
Odpowiedzialność - według Ojca Świętego - dotyczy nie tylko treści przekazu, ale również sposobu realizacji i dróg przekazywania. Chodzi tu także o wszelkie okoliczności, takie jak: cel, miejsce, osoby, czas, które mogą mieć wpływ na wymowę przekazu i ocenę moralną. Odpowiedzialność -zdaniem Papieża - uwidacznia się szczególnie wtedy, gdy bierze się pod uwagę przewidywany wpływ przekazu na odbiorców. „W sytuacji różnic politycznych i światopoglądowych - mówił Jan Paweł II do dziennikarzy i artystów - przed dziennikarzami stoi nieustannie zadanie konfrontowania swej myśli z innymi ujęciami i stanowiskami, zadanie rozpoznawania i prezentowania publicznie tendencji ideologicznych, a także wyjaśniania i uściślania własnego stanowiska. Ta wielka szansa niesie zarazem wielką odpowiedzialność" 57.

W przekonaniu Jana Pawła II, mass media mogą odegrać pozytywną rolę w budowaniu jedności w świecie, ale równocześnie, co podkreśla Papież, mogą podsycać konflikty społeczne, polityczne, rewindykacje narodowe, prowadzić do wyścigu zbrojeń. Mogą wpływać na formowanie sposobu myślenia pokojowego lub „nastawionego na rozwiązania przy pomocy siły”58.

Problem odpowiedzialności uczynił Papież głównym motywem Orędzia na Światowy Dzień Środków Społecznego Przekazu w roku 1981. W przemówieniu do dziennikarzy wygłoszonym tuż przed wydaniem tegoż orędzia, Papież określił doktrynalne podstawy odpowiedzialności - powiązał odpowiedzialność z wolnością. „Bowiem jedynie w sytuacji wolności i poprzez odpowiedzialną wolność będziecie mogli wypełnić waszą misję obserwatorów i informatorów"59. Wolność - w rozumieniu Jana Pawła II - nie oznacza możliwości czynienia wszystkiego, co się zechce, uwolnienia się od zasad i norm moralnych. Pojęcie wolności jest podstawowym pytaniem i odpowiedzią zarazem na temat ludzkiej moralności. Wolność jawi się - wskazuje papież - jako coś, co człowiek rozpoznaje wraz z odpowiedzialnością ${ }^{60}$. Tak rozumując, można - naucza Jana Pawła II - określić następująco zasadę pracy dziennikarskiej: „,informować lepiej, aby być bardziej odpowiedzialnymi i bardziej wolnymi" ${ }^{1}$.

Przekaz informacji staje się sposobem, „w jaki każdy człowiek dobrowolnie przyjmuje na siebie większą odpowiedzialność za losy ludzkości”"62. Człowiek bowiem może odpowiadać jedynie za to, co jest mu znane. „Bez

${ }^{57}$ JAN PAWE⿺ II, Kościót potrzebuje sztuki, dz. cyt., s. 19.

${ }^{58}$ JAN PAWE⿺ II, Środki spotecznego przekazu w stużbie pokoju, „L'Osservatore Romano” 4 (1983), s. 6.

${ }^{59}$ JAN PAWEE II, Informacja, odpowiedzialna wolność, ,L'Osservatore Romano” 2 (1981), s. 24.

${ }^{60}$ Por. A. Frossard, Nie leckajcie się! Rozmowy z Janem Pawtem II, Watykan 1982, s. 119-121.

${ }^{61}$ JAN PAWEE II, Informacja, odpowiedzialna wolność, dz. cyt., s. 24.

62 Tamże. 
dobrej informacji nie może być mowy o spełnianiu odpowiedzialności, ponieważ odpowiedzialna wolność ludzkości zależy od dokładnego zrozumienia i odnowionej koordynacji wiadomości z całego świata"63.

$\mathrm{Z}$ drugiej jednak strony, odpowiedzialna wolność twórców przekazu społecznego nie może nie brać pod uwagę faktu, iż także odbiorcy są wolni i odpowiedzialni. Z ich wolnością muszą się liczyć środowiska twórcze.

Srodki przekazu posiadają prawo wyboru i selekcji materiałów - wynika to z samej natury przekazu. Nie zmniejsza to jednak odpowiedzialności w dziedzinie wyboru. Wprost przeciwnie, ponieważ selekcja jest nieunikniona, wzrasta odpowiedzialność tych, którzy dysponują możliwościami wyboru. Odpowiedzialność nie odnosi się jedynie do treści, dotyczy także formy przekazu. Telewizja oparta na sugestywnych środkach ekspresji, czerpie coraz częściej ze zdobyczy nauk społecznych i psychologicznych, sprawdzonych w handlu i reklamie. Trzeba dodać, że nie zawsze są one w godziwy sposób wykorzystywane w produkcji telewizyjnej. Do metod uatrakcyjniania przekazu należy np. bazowanie na zmysłowości lub wręcz pornografii. Takie formy przyciagania widzów do telewizora, wzbudzania zainteresowania przekazem Kościół uważa za niegodne misji, jaką wiąże z naturą społecznego i masowego przekazu ${ }^{64}$.

Odpowiedzialność twórców dotyczy w szczególny sposób programów o charakterze religijnym. Chodzi o kształtowanie zdrowej opinii publicznej w dziedzinie moralności i religii. „Aby położyć kres - pisze Jan Paweł II - szerzeniu się permisywizmu i obojętności religijnej, trzeba się starać o to, by opinia publiczna respektowała i ceniła wartości moralne i religijne, które czynią człowieka w pełni ludzkim i nadają życiu pełny sens. Współczesna ludzkość bowiem zagrożona jest nihilizmem, czyli utratą wartości najbardziej ludzkich, moralnych i religijnych" ${ }^{5}$. Do pilnych zadań twórców społecznego przekazu należy więc tak kształtować opinię publiczną, by właściwie pojmowała naturę, posłannictwo i dzieło Kościoła. Wielu ludzi z powodu nieprawidłowego obrazu religii w mediach widzi Kościół jako strukturę tylko ludzką, „nie zaś to, czym jest naprawdę, czyli tajemniczą rzeczywistość wcielającą w historię miłość Boga i niosącą ludziom słowo i łaskę Chrystusa"66.

Papież Paweł VI naucza, iż do informacji religijnej czy programu religijnego stosuje się wszystkie wskazania dotyczące społecznego przekazu, a zwłaszcza odpowiedzialność. Papież podkreśla, że nie brak w tej sprawie barier i przeszkód. „Nie wszyscy, nawet pośród informatorów kościelnych,

${ }^{63}$ Tamże.

${ }^{64}$ Por. JAN PAwEx II, Środki społecznego przekazu w stużbie odpowiedzialnej wolności, „L’Osservatore Romano" 5 (1981), s. 5.

${ }^{65}$ JAN PAWEe II, Kształtowanie opinii publicznej, „L'Osservatore Romano” 1 (1986), s. 28.

${ }^{66}$ Tamże. 
znają prawdziwą naturę Kościoła, jego autentyczną misję, co może wpływać negatywnie na sposób przyjmowania i podawania informacji. Stąd potrzeba cierpliwości, kontaktów wymagających trudu i taktu, zrozumienia oraz roztropnego, inteligentnie wyjaśniającego i pełnego lojalności dialogu, aby usunąc istniejące trudności" ${ }^{67}$.

Jan Paweł II podkreśla, ,że Kościół stara się i będzie się starał coraz bardziej być «domem ze szkła», by wszyscy mogli widzieć, co w nim się dzieje i jak on pełni swoją misję w wierności Chrystusowi i ewangelicznemu orędziu"68. Ale z drugiej strony, Kościół oczekuje podobnego wysiłku autentyczności ze strony tych, którzy z racji pełnionych funkcji obserwatora rzeczywistości mają przekazywać drugim informacje o życiu i działalności Kościoła. „Powraca tu -zdaniem Papieża - analogia między misją Kościoła i misją dziennikarstwa, zawarta w tej szerszej misji świata komunikacji. Analogia między zaangażowaniem Kościoła w dzieło realizacji wskazań Soboru Watykańskiego II a tym, do którego wezwane jest społeczeństwo, by iść naprzód po drodze postępu naznaczonego pokojem i sprawiedliwością" ${ }^{69}$.

Jan Paweł II w swoim nauczaniu o mediach wskazuje na rosnącą rolę i odpowiedzialność środowiska katolickich twórców. Lepszy przebieg idei i informacji wewnątrz wspólnoty kościelnej, między Stolicą Apostolską i Kościołami lokalnymi, może niewątpliwie przyczynić się do pogłębienia ducha kolegialności i wzmocnienia jedności, ,ale także do wzrostu i dojrzewania osobistej i zbiorowej świadomości członków ludu Bożego"70. To tłumaczy dlaczego dziś misja dziennikarza, szczególnie katolickiego, wymaga kompetencji zawodowej i odpowiedzialności moralnej.

Kraków

KS. ANDRZEJ BACZYŃSKI

\section{Riassunto}

Le norme per la realizzazione dei programmi religiosi nei mezzi audiovisivi

L'istruzione pastorale Communio et progressio dice brevemente in riguardo ai programmi religiosi nella radio e nella televisione: "Gli aspetti religiosi della vita umana devono prendere luogo degno e stabile nei programmi” (CP 149). Il termine programma religioso, benché spesso adoperato, non è troppo preciso e non corrisponde pienamente alla realtà televisiva, in cui funziona. Esso ricorre alla formula isolata dei programmi ristretti tematicamente. Non dobbiamo aggiungere, che questo tipo di qualificazione non è una soluzione migliore per la presenza della Chiesa in mass media, poiché limita il potenziale pubblico per causa della troppa specializzazione.

${ }^{67}$ PAwet VI, Prawda: Podstawowe kryterium środków społecznego przekazu, [w:] tenże, Nauczanie społeczne 1972-73, T. I, Warszawa 1975, s. 39.

${ }^{68}$ Jan Pawet II do dziennikarzy, ,Tygodnik Powszechny” 7 (1984), s. 2.

${ }^{69}$ Tamże.

${ }^{70}$ Tamże. 
La Chiesa vuole che tutti i programmi televisivi, liberi dalla falsità, trasmettano la verità sull'uomo e sul mondo, difendino la dignità umana e si dichiarino in favore del bene, della bellezza e della giustizia. I programmi che rispettano questi valori si trovano nel centro dell'interesse della Chiesa. Essi si riferiscono al contesto religioso, benché esso non sia chiaramente legato alla Chiesa oppure alla religione.

Il programma religioso, dal punto di vista formale, si sottomette alle stesse regole come tutta la produzione televisiva. Il professionismo, la conoscenza della problematica televisiva, come pure del linguaggio audiovisivo, l'onesto lavoro e la competenza - sono fondamenti del lavoro degli autori dei programmi televisivi, anche di quelli detti religiosi. Il criterio basilare di valutare questi programmi è la loro relazione con la verità. Il diritto e il dovere principale di ogni sorte della trasmissione televisiva, secondo l'insegnamento della Chiesa, sono la sincerità, la veracità e la verità. 